\title{
Nuclear Receptor Coactivator 3
}

National Cancer Institute

\section{Source}

National Cancer Institute. Nuclear Receptor Coactivator 3. NCI Thesaurus. Code C18172.

Nuclear receptor coactivator $3(1424 \mathrm{aa}, \sim 155 \mathrm{kDa})$ is encoded by the human NCOA3

gene. This protein is involved in the mediation of hormone-stimulated gene expression. 